\title{
Perilaku Prososial pada Relawan Anak Sumatera Selatan
}

\author{
Muhammad Nurahman Hidayatullah ${ }^{\mathrm{a} *}$, Lukmawati ${ }^{\mathrm{b}}$, Ris'an Rusli ${ }^{\mathrm{c}}$ \\ ${ }^{a, b, c}$ Universitas Islam Negeri Raden Fatah Palembang
}

*Corresponding author: imannrahman909@gmail.com

\begin{abstract}
Abstrak
Penelitian ini bertujuan untuk mengetahui bagaimana perilaku prososial pada Relawan Anak Sumatera Selatan. Penelitian ini menggunakan metode penelitian kualitatif dengan pendekatan deskriptif kualitatif, yang dilakukan untuk mengeksplor fenomena-fenomena yang pernah terjadi dilingkungan sekitar peneliti dengan tujuan agar dapat menjadi suatu penilaianpenilaian masyarakat terhadap suatu fenomena yang terjadi. Berdasarkan hasil penelitian ini dapat disimpulkan bahwa gambaran perilaku prososial kedua subjek yaitu membantu tanpa meminta balasan (pamrih), ikhlas, dan jujur dengan harapan dapat membantu banyak pihak seperti pemerintah untuk mengurangi tingkat anak jalanan, kemudian dapat membantu masyarakat untuk mengurangi rasa gelisah karena kehadiran mereka yang dianggap menganggu, dan membantu anak jalanan itu sendiri.
\end{abstract}

\section{Kata Kunci}

Perilaku prososial; Relawan; Kualitatif

\begin{abstract}
This study uses a qualitative research method with a qualitative descriptive approach, which is carried out to explore phenomena that have occurred in the environment around researchers in order to become a community assessments of a phenomenon that occurs. Based on the results of this study it can be concluded that the description of prosocial behavior of the two subjects is help without asking for a reply (sincere), sincere, and honest in the hope that it can help many parties such as the government to reduce the level of street children, then can help the community to reduce anxiety because of their presence which is considered disturbing, and helps street children themselves.
\end{abstract}

\section{Keywords}

Prosocial behaviour; Voluntarily; Qualitative 


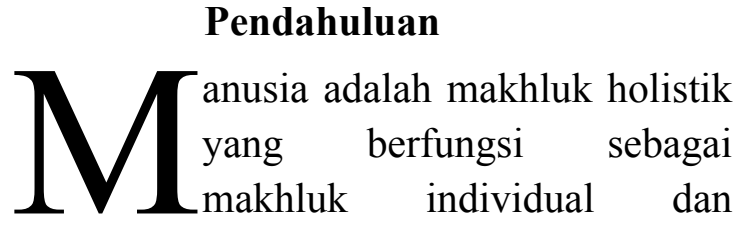
makhluk sosial yang membutuhkan orang lain. Manusia sebagai makhluk individual karena manusia memiliki kepribadian masing-masing yang mampu ia kembangkan sendiri. Sedangkan Sears mengatakan bahwa manusia tidak sematamata merupakan makhluk individual yang bisa hidup sendiri, melainkan manusia merupakan makhluk sosial yang hidupnya bergantung pada orang lain. Sebagai makhluk sosial, manusia harus bisa berinteraksi dan bersosialisasi dengan orang lain karena kehidupan manusia akan berlanjut dan berarti apabila dirinya mampu hidup bersama dengan orang lain dalam memenuhi kebutuhan serta tujuan hidupnya (Prawitasari, 2007).

Untuk memenuhi kebutuhan dan tujuan tersebut maka diperlukan sebuah tindakan sosial, tindakan yang dianggap baik dan mulia serta bermanfaat bagi orang lain yang membutuhkan merupakan tindakan tolong menolong sesama manusia, karena manusia membutuhkan orang lain maka dengan tindakan tersebut memungkinkan manusia lain juga akan menolongnya jika ia membutuhkan pertolongan. Tindakan ini biasanya disebut sebagai perilaku prososial atau perilaku memberi tanpa meminta (pamrih). Dalam penelitian ini perilaku prososial dilakukan untuk anak-anak jalanan yang luntang-lantung dijalanan tanpa keluarga.Peneliti tertarik karena anak jalanan merupakan masalah sosial yang menjadi fenomena menarik dalam kehidupan bermasyarakat khususnya di Indonesia. Kita bisa menjumpai anak-anak yang sebagian besar hidupnya berada di jalanan pada berbagai titik pusat keramaian di kota besar, seperti di pasar, terminal, stasiun, traffic light, pusat pertokoan, dan sebagainya. Kehidupan mereka terutamaberhubungan dengan kegiatan ekonomi, antara lain mengamen, mengemis. mengasong, kuli, loper koran, pembersih mobil, dan sebagainya. Meskipun ada pula sekumpulan anak yang hanya berkeliaran atau berkumpul tanpa tujuan di jalanan (Suyanto, 2010). Menurut United Nations International Children's Fund (UNICEF) jumlah anak jalanan di dunia mencapai 100 juta jiwa, 30 juta diantaranya terdapat di Asia (Arifin, 2001).

Sedangkan, menurut data Pusat Data dan Informasi Kesejahteraan Kementerian Sosial, hingga Agustus 2017 jumlah anak jalanan tersisa sebanyak 16.290. Sebelumnya, jumlah anak jalanan di seluruh Indonesia pada 2006 sebanyak 232.894 anak, pada 2010 sebanyak 159.230 anak, pada 2011 turun menjadi 67.607 anak, dan pada 2015 menjadi 33.400 anak. Seluruh anak jalanan tersebut tersebar di 21 provinsi (Kemensos, 2011). Data anak jalanan khusunya di Sumsel menurut Kabid Pelayanan dan Rehabilitasi Dinas Sosial Sumsel, Leni Triana mengatakan bahwa data penyandang Masalah Kesejahteraan Sosial (PMKS) di Sumsel sendiri tahun 2017 mencapai 1.156 anak. Terdiri dari anak yang membutuhkan perlindungan khusus mencapai 50 anak, anak jalanan 200 anak, anak Terlantar 710 anak, anak berhadapan hukum 46 anak dan anak balita terlantar mencapai 150 anak (Depsos RI, 2007).

Anak-anak jalanan tersebut berada pada rentang usia 8-12 tahun dimana menurut Hurlock (2010), usia tersebut termasuk 
pada masa kanak-kanak akhir. Kehidupan mereka banyak dihabiskan dijalanan untuk bekerja mencari nafkah dengan mengamen, berjualan koran, berjualan tisu, makanan kecil atau bajkan meminta-minta. Hal ini bertentangan dengan tugas-tugas perkembangan menurut teori Havigurst (dalam Hurlock, 2010) yaitu dimasa mereka harusnya belajar keterampilan fisik untuk permainan umum, mengembangkan ketrampilan dasar membaca, menulis dan berhitung, belajar berinteraksi dengan teman sebaya, mengembangkan pengertian dalam kehidupan sehari dan sebagainya.

Kasus anak jalanan ini bisa diminimalisir dengan melakukan upaya perlindungan dan pemberian hak kepada anak jalanan. Adapun Upaya pemerintah melindungi anak diwujudkan lewat pengembangan Kota Layak Anak (KLA) yaitu kota yang menjamin hak setiap anak sebagai warga. Salah satu upaya tersebut diwujudkan dengan memajukan pendidikan untuk melahirkan sumber daya manusia yang berkualitas (Mutrofin, 2009). Penyelenggaraan pendidikan dan suasana belajar yang ideal akan mengembangkan kepribadian dan meningkatkan kecerdasan generasi penerus sesuai minat dan bakatnya. Dalam UU RI No. 20 tahun 2003 tentang Sistem Pendidikan Nasional, pemerintah menetapkan jenjang pendidikan formal. Ada pula jalur pendidikan nonformal yang diselenggarakan bagi masyarakat yang memerlukan layanan pendidikan sebagai pengganti dan pelengkap pendidikan formal, yang hasilnya dapat dihargai setara dengan hasil pendidikan formal setelah melalui proses penilaian penyetaraan oleh pemerintah.

Pendidikan yang dilakukan sebagai upaya meminimalisir anak jalanan tersebut dilakukan karena dampak yang dialami dan dirasakan oleh anak jalanan cukup berat. Dampak tersebut bisa menyebabkan keadaan psikologis yang buruk bagi anak jalanan, karena mereka yang seharusnya di beri kasih sayang penuh oleh keluarga dan mendapat perhatian khusus dari orang tuanya malah menghabiskan waktunya di jalanan dan mencari makan serta uang sendiri. Karena hal tersebut maka anakanak jalanan sangat membutuhkan dukungan dan bantuanorang lain atau masayarakat yang bersedia menolong anakanak tersebut dengan ikhlas tanpa mengharapkan balasan. Dalam hal ini perilaku tersebut disebut sebagai perilaku prososial.

Baron dan Byrne (2005) menyatakan bahwa perilaku prososial atau tindakan menolong merupakan tindakan terpuji dan menguntungkan orang lain yang ditolong tanpa mendapat keuntungan kembali, bahkan mungkin dapat merugikan orang yang menolong. Perilaku prososial menurut William James adalah tingkah laku seseorang yang bermaksud untuk merubah keadaan psikis dan fisik si penerima sedemikian rupa, sehingga penolong akan merasa bahwa si penerima menjadi lebih sejahtera atau puas secara material ataupun psikologis. Pengertian ini menekankan pada maksud dari perilaku untuk menciptakan kesejahteraan fisik maupun psikis. Selanjutnya Eisenberg dan Mussen (1989) menyatakan bahwa perilaku prososial merupakan tindakan sukarela untuk membantu dan memberi pertolongan kepada orang lain sehingga orang yang ditolong akan diuntungkan. Sedangkan Mussen menyatakan bahwa perilaku prososial dilakukan secara sukarela dan bukan karena paksaan, aspek perilaku prososial meliputi 1) Menolong yaitu 
kesediaan untuk menolong orang lain yang sedang berada dalam kesulitan. 2) Bederma yaitu kesediaan untuk memberikan sebagian barang miliknya kepada orang yang membutuhkan secara sukarela tanpa mengharapkan balasan dari orang yang ditolong. 3) Kerjasama yaitu kesediaan untuk bekerjasama dengan orang lain demi tercapainya suatu tujuan. 4) Berbagi Perasaan yaitu kesediaan untuk berbagi perasaan dengan orang lain dalam suasana suka dan duka. 5) Bertindak jujur yaitu kesediaan untuk melakukan sesuatu seperti apa adanya, tidak berbuat curangperilaku menolong, berbagi, kerjasama, altruisme, dan berperilaku jujur (Asih \& Pratiwi, 2010). Jadi, dapat disimpulkan bahwa perilaku prososial adalah suatu tindakan memberi dengan sukarela pada orang yang membutuhkan dengan tujuan untuk membantunya yang berada dalam kesulitan. Sedangkan aspek-aspek dari perilaku prososial adalah menolong, bederma, bekerja sama, berbagi perasaan duka maupun duka serta berlaku jujur seperti menunjukkan sesuatu dengan apa adanya.

Relawan adalah seseorang atau sekelompok orang yang membantu secara ikhlas berdasarkan hati nuraninya sendiri dengan memberikan apa yang dimilikinya (ekonomi, waktu, fikiran tenaga dan sebagainya) kepada sekelompok masyarakat yang membutuhkan, sebagai rasa tanggung jawabnya tanpa mengharapkan pamrih atau imbalan seperti uang, jabatan, karir atau kepentingan lainnya. Sedangkan dalam bidang sosial mendefinisikan relawan sebagai anggota kesejahteraan sosial tanpa bersekolah khusus dari sekolah pekerjaan sosial atau ilmu kesejahteraan sosial (Tobing, dkk., 2008; Nugrghi, \& Tehuteru, 2008). Tujuan dari relawan adalah untuk memanusiakan manusia dan membantu orang lain yang membutuhkan (Taylor, 2009).

Relawan yang bertujuan untuk membantu serta memanusiakan orang lain ada banyak jenisnya, karena relawan tidak sebatas pada satu bidang saja. Adapun jenis-jenis relawan menurut Mitcell (Tobing, dkk., 2008; Nugrghi, \& Tehuteru, 2008). yaitu: 1) policy making volunteers, yaitu para relawan yang membuat kebijakan mengenai tugas-tugas yang akan diberikan, komisi dan dewan. 2) Administrative volunteers, yaitu relawan administrasi yang menawarkan bantuan untuk mengelola perkantoran seperti pengolahan data, mengkoordinasi jadwal dan mengurus surat-menyurat yang diperlukan. 3) Advocacy volunteers, yaitu relawan advokasi yang memberi bantuan berupa pencarian dana, menulis surat-menyurat dan menghubungi para dewan, memberikan kesaksian pada sidang public dan berkerja di bidang hubungan masyarakat. 4) Direct Service Volunteers, yaitu relawan pelayanan yang terlibat dalam aktivitasaktivitas seperti konseling, rekreasi dan pengajaran terhadap masyarakat. Jika dilihat dari jenis-jenis relawan diatas peran relawan mirip dengan pekerja sosial (Social Worker), Fungsi pekerjaan sosial oleh pekerja sosial adalah melaksanakan peranan sosial serta proses-prosesnya yang bertujuan untuk memperbaiki dan mengembangkan kepribadian dan system sosial.

Fink dan Adi (Adi, 2005) menyatakan ada beberapa bidang sosial yang dapat dilakukan oleh pekerja sosial dimana salah satu diantaranya adalah bidang yang terkait dengan pelayanan kesehatan. Pekerja sosial yang biasanya terjun dalam bidang ini 
disebut sebagai pekerja sosial medis (PSM). Adapun peran PSM adalah: 1) konsultan, menerima rujukan dan konsul dari profesi yang terkait. 2) mengumpulkan data atau informasi mengenai kasus atau masalah yang ditangani. 3) pembimbing dalam pemecahan kasus yang ditangani. 4) pejabat bantuan rumah sakit, memberi saran banyuan yang tepat kepada klien melalu manajemen rumah sakit. Pendampingan yang dilakukan baik oleh pekerja sosial maupun oleh relawan hampir sama, perbedaannya terletak pada pemberian konseling dan koordinasi dengan bidang-bidang yang terkait pada permasalahan korban yang mana masalah tersebut lebih didominasi oleh pekerja sosial. Sehingga secara garis besar perbedaan relawan dan pekerja sosial terletak pada latar belakang pendidikan dan pelatihan dalam mendapatkan bekal. Pekerja sosial merupakan lulusan atau mendapatkan pendidikan khusus dari sekolah pekerjaan sosial atau ilmu kesejahteraan sosial sedangkan relawan bukan lulusan dari sekolah pekerjaan sosial yang artinya siapapun orang yang bersedia memberikan bantuan kepada orang lain dengan ikhlas tanpa pamrih disebut sebagai relawan (Adi, 2005).

Relawan adalah seseorang atau sekelompok orang yang membantu secara ikhlas berdasarkan hati nuraninya sendiri dengan memberikan apa yang dimilikinya untuk masyarakat yang membutuhkan. Beberapa kontribusi yang diberikan para relawan khususnya pada anak-anak jalanan adalah memberikan bekal pengetahuan seperti belajar, berbagi ilmu pengetahuan dan melatih kreativitas (Soft kill) dalam bentuk monitoring serta bermain games agar anakanak merasa terhibur. Hal itu dilakukan untuk melakukan pendekatan antara relawan dengan anak-anak jalanan. Relawan tersebut juga meluangkan waktu, tenaga dan materi untuk dapat berbagi dengan anak-anak jalanan melalui suatu kegiatan. Kegiatan yang diselenggarakan oleh para relawan dengan alasan bahwa mereka merasa empati yaitu merasakan apa yang mereka rasakan dan perihatin atas apa yang di alami oleh anak-anak jalanan tersebut. Hal ini sesuai dengan pernyataan Goleman (2007) yang menyatakan bahwa empati adalah kemampuan untuk memahami perasaan dan masalah orang lain, berfikir dengan sudut pandang mereka serta menghargai perbedaan perasaan orang lain tentang berbagai hal. Relawan rela meluangkan waktu dan tenaga tanpa mengharapkan keuntungan ataupun upah secara finansial demi kesejahteraan anakanak jalanan dan menjadi suatu kebahagiaan tersendiri bagi relawan karena diajarkan dan mencontoh perlakuan orang tua, keluarga, masyarakat dan lingkungan sekitar relawan yang mana hal ini dianggap sebagai hal yang mulia dan patut dicontoh. Perilaku ini digambarkan oleh teori belajar sosial Bandura, di mana teori ini menyatakan bahwa perilaku prososial disebabkan oleh proses belajar, Bandura mengaplikasikan pendekatan ini pada perilaku sosial yang dinamakan social learning theory (teori belajar sosial). Dalam pembelajaran terdapat tiga mekanisme umum yang terjadi dalam proses belajar yaitu asosiasi, reinforcement (penguatan) dan observational learning (belajar observasi) dimana seseorang belajar melalui modeling yaitu mengamati perilaku seseorang yang memberi pertolongan untuk orang lain (Sarwono \& Meinarno, 2009).

Berdasarkan fenomena diatas dan penelitian terdahulu maka peneliti tertarik untuk melakukan penelitian metode 
kualitatif pada relawan, adapun pertanyaan yang akan dipergunakan pada penelitian yaitu bagaimana perilaku prososial pada relawan anak Sumatera Selatan.

\section{Metode}

Pada penelitian ini menggunakan jenis penelitian kualitatif deskriptif. Metode kualitatif ialah suatu metode pengumpulan data dengan lebih menekankan analisisnya pada proses penyimpulan deduktif dan induktif serta pada analisi terhadap dinamika hubungan antar fenomena yang diamati, denan menggunakan logika ilmiah (Azwar, 1998).

Creswell menyatakan bahwa penelitian Kualitatif adalah suatu proses penelitian ilmiah yang lebih dimaksudkan untuk memahami masalah-masalah manusia dalam konteks sosial dengan menciptakan gambaran menyeluruh dan kompleks yang disajikan, melaporkan pandangan terperinci dari sumber informasi, serta dilakukan dalam setting yang alamiah tanpa adanya intervensi apa pun dari peneliti (Herdiyansyah, 2010).

Berdasarkan penjelasan diatas maka alasan peneliti menggunakan metode penelitian kualitatif dengan pendekatan deskritif dikarenakan peneliti ingin mengambarkan perilaku prososial pada relawan yang diteliti. Dengan kata lain, penelitian deskritif berusaha untuk menciptakan gambaran menyeluruh dan kompleks yang disajikan, melaporkan pandangan terperinci dari sumber informasi, serta dilakukan dalam setting yang alamiah tanpa adanya intervensi apa pun dari peneliti.

\section{Subjek Penelitian}

Subjek yang digunakan berjumlah dua orang memiliki karakter sebagai berikut:

a. Relawan aktif di komunitas Relawan Anak Sumatera Selatandi Palembang.

b. Melakukan perilaku prososial dan memberikan kontribusi yang besar terhadap anak Jalanan.

c. Subjek bersedia membantu dan memberikan informasi terkait penelitian.

\section{Teknik Pengumpulan Data}

Peneliti menggunakan tiga macam teknik pengumpulan data berupa:

\section{Observasi}

Observasi berasal dari bahasa latin yang berarti memperhatikan dan mengikuti. Memperhatikan dan mengikuti dalam arti mengamati dengan teliti dan sistematis. Observasi adalah suatu kegiatan mencari data yang dapat digunakan untuk memberikan suatu kesimpulan atau diagnosis. Inti dari observasi adalah adanya perilaku yang tampak dan adanya tujuan yang ingin dicapai. Perilaku orang yang dapat diobservasi berupa perilaku yang dapat dilihat langsung oleh mata, dapat dihitung, dan dapat di ukur.

Namun, dalam penelitian ini peneliti menggunakan metode observasi anecdotal record (catatan anekdot). Catatan anekdot adalah cara pengumpulan data melalui pengamatan langsung tentang sikap dan perilaku seseorang yang muncul secara tiba-tiba (peristiwa yang terjadi secara insidental). Anecdotal record (catatan kejadian khusus) merupakan uraian tertulis mengenai perilaku yang ditampilkan oleh seseorang dalam situasi khusus (Herdiansyah, 2010). 


\section{Wawancara}

Wawancara merupakan metode pengumpulan data yang digunakan pada hampir semua penelitian kualitatif karena seringnya wawancara digunakan dalam penelitian kualitatif, seakan-akan wawancara menjadi ikon dalam metode pengumpullan data penelitian kualitatif.

Menurut Moleong (2013) wawancara adalah percakapan dengan maksud tertentu. Percakapan dilakukan oleh dua pihak, yaitu pewawancara (interviewer) yang mengajukan pertanyaan dan terwawancara (interviewee). Pendekatan wawancara dalam penelitian ini menggunakan wawancara mendalam (indepth interview).

Wawancara mendalam (indepth interview) adalah proses memperoleh keterangan untuk tujuan penelitian dengan cara tanya jawab sambil bertatap muka antara interviewer dengan informan atau orang yang diwawancarai, dengan atau tanpa menggunakan pedoman wawancara, di mana pewawancara dan informan terlibat dalam kehidupan sosial yang relatif lama (Sutopo, 2006).

\section{Dokumentasi}

Studi dokumentasi adalah salah satu metode pengumpulan data kualitatif dengan melihat atau menganalisis dokumendokumen yang dibuat oleh subjek sendiri atau oleh orang lain tentang subjek. studi dokumentasi merupakan salah satu cara yang dapat dilakukan penelitian kualitatif untuk mendapatkan gambaran dari sudut pandang subjek melalui suatu media tertulis dan dokumen lainnya yang ditulis atau dibuat langsung oleh subjek yang bersangkutan (Herdiansyah, 2010).
Adapun dokumentasi yang digunakan dalam penelitian ini berupa video, foto serta rekaman wawancara yang dilakukan peneliti pada subjek relawan jalanan yang berolokasi di plaju.

\section{Metode Analisis Data}

Menurut Milles and Huberman, analisis data tertata dalam situs ditegaskan bahwa kolom pada sebuah matriks tata waktu disusun dengan jangka waktu, dalam susunan tahapan, sehingga dapat dilihat kapan gejala tertentu terjadi. Prinsip dasarnya adalah kronologi (Miles dan Huberman, 2007).

Untuk menyajikan data agar mudah dipahami, maka langkah-langkah anlisis data yang digunakan dalam penelitian ini adalah Analysis Interactive Model dari Miles dan Huberman (2007), yang membagi langkah-langkah dalam kegiatan analisis data dengan beberapa bagian yaitu pengumpulan data (data collection), reduksi data (data reduction), penyajian data (data display), dan penarikan kesimpulan atau verifikasi (conclutions).

\section{Hasil dan Diskusi}

Penelitian ini membahas mengenai gambaran perilaku prososial pada relawan Anak Sumatera Selatan dan faktor-faktor yang mempengaruhi perilaku prososial pada relawan Anak Sumatera Selatan.

Adapun subjek dalam penelitian ini merupakan remaja berinisial "JEM" dan "YH". Subjek pertama berinisial "JEM" subjek lahir pada tanggal 03 Januari 1997 yang berarti saat ini usia subjek 22 tahun. Latar belakang subjek menjadi relawan adalah karena subjek memiliki jiwa sosial yang tinggi sehingga ingin bermanfaat 
untuk orang lain, bukan menjadi mahasiswa kupu-kupu, yaitu kuliah-pulang, kuliahpulang. Subjek "JEM" bergabung menjadi relawan sejak tahun 2018 hingga saat ini. Kegiatan sehari-hari subjek selain menjadi relawan adalah kuliah khususnya disibukkan dengan penyusunan skripsi dan menjadi financer dalam konsultan pajak, adapun persiapan subjek sebelum menjadi relawan yaitu hanya mengikuti alur kegiatan disana sehingga mendapat ilmuilmu yang tidak didapat dari bangku perkuliahan. Subjek kedua yang berinisial "YH", berusia 22 tahun. Subjek lahir pada tanggal 02 Juli 1997 berasal dari kota Lubuk Linggau. Latar belakang subjek menjadi relawan adalah subjek awalnya hanya sebagai volunteer biasa yang kemudian diangkat menjadi kepengurusan dalam komunitas RASS. Subjek bergabung menjadi relawan sejak tahun 2019. Kegiatan sehari-hari subjek selain menjadi relawan adalah bekerja karena subjek "YH" baru saja menyelesaikan perkuliahannya, karena hal inilah subjek menjadi sibuk dan jarang mengikuti kegiatan komunitas. Adapun persiapan subjek sebelum menjadi relawan adalah niat, karena jika seseorang sudah berniat maka semua akan menjadi mudah. Dilihat dari usia kedua subjek termasuk pada ketegori dewasa awal yaitu periode perkembangan yang dimulai pada awal usia 20-an sampai usia 30-an. Pada masa ini individu semakin sehat sehingga memungkinkan mereka utuk lebih aktif dan produktif. Masa ini merupakan saat untuk mencapai kemandirian pribadi dan ekonomi, perkembangan karir, dan masa untuk mencari pasangan (Santrock, 2012).

Alasan subjek berinisial "JEM" bergabung menjadi relawan karena jiwa sosialnya tinggi, subjek membutuhkan wadah untuk berkontribusi dan mengembangkan idenya serta ingin bermanfaat bagi orang lain sehingga menurutnya komuntas RASS adalah komunitas yang menarik untuk diikuti. Pandangan subjek "JEM" mengenai anak jalanan ialah anak jalanan sama halanya dengan anak lain yang membedakan hanyalah faktor ekonomi dan faktor sosial di mana masyarakat menganggap buruk mereka karena luntang lantung dijalanan sebagaimana menurut Mintanawati (2018) Anak jalanan dalam pandangan masyarakat adalah anakanak yang susah diatur, senang mabuk-mabukan dan "ngelem", penganut free sex, liar, senang berkelahi, dan lain-lain. Subjek kedua berinisial "YH" alasan bergabung menjadi relawan Anak Sumatera Selatan karena subjek cinta pada dunia sosial sehingga memilih bergabung dalam komunitas RASS yang kebetulan satu hati pada subjek yang juga bergerak dalam bidang sosial. Pandangan subjek mengenai anak jalanan ialah subjek merasa simpati dan ikut sedih melihat keadaan mereka di mana seharusnya mereka bermain dan belajar bersama teman seusianya bukan malah berkeliaran di "jalan sambil menjual koran, karena itulah diperlukan komunitas RASS untuk membantu mereka. Hal ini sejalan menurut Departemen Sosial RI (2005), anak jalanan adalah anak yang menghabiskan sebagian besar waktunya untuk melakukan kegiatan hidup seharihari di jalanan, baik untuk mencari nafkah atau berkeliaran di jalan dan tempat-tempat umum lainnya.

Mengenai konstribusi subjek sebagai relawan Anak Sumatera Selatan dan cara subjek melakukan pendekatan dengan anak jalanan. Subjek pertama yang berinisal "JEM" memberikan kontribusi kepada anak jalanan berupa pakaian dan alat tulis yang masih layak serta pengajaran atau edukasi 
kepada mereka, Selain itu subjek "JEM" memberi kontribusi dengan mengikuti event-event yang dilaksanakan komunitas. Adapun cara subjek melakukan pendekatan dengan mengikuti keinginanan anak-anak sehingga mereka tidak takut untuk dekat dengan subjek, Selain itu untuk lebih dekat pada anak jalanan, para relawan mengadakan event atau acara. Subjek kedua yang berinisial "YH" memberi kontribusi berupa pakaian dan alat tulis yang tidak digunakan lagi tapi masih layak digunakan, kontribusi tersebut diberikan dengan harapan mereka bisa belajar dengan baik serta tidak malu untuk berpakaian kurang layak. Sebagaimana karakteristik anak jalanan di rumah singgah anak mandiri ialah berpakaian kurang memenuhi aspek kebersihan, pakaian nampak lusuh, kotor dan sobek (Lukman \& Sujarwo, 2012). Adapun cara subjek melakukan pendekatan dengan anak jalanan yaitu dengan mengajak mereka bercanda, bermain dan menghibur mereka sehingga mereka langsung dekat dengan subjek.

Subjek "JEM" menganggap bahwa pertolongan dari relawan itu sangat penting dalam mengurangi jumlah anak jalanan yang tidak bisa terselesaikan oleh dinas sosial, pertolongan tersebut berupa pengajaran dan edukasi oleh relawan pada anak-anak. Selain itu, untuk membantu beban psikis subjek "JEM" mengusulkan adanya kakak asuh khusus untuk mengawasi perkembangan mereka sehingga mereka merasa diperhatikan dan disayang. Untuk faktor ekonomi relawan membantu menyalurkan donasi-donasi yang diberikan para donatur untuk anakanak jalanan. Adapun cara subjek "JEM" memotivasi anak jalanan yaitu dengan menerapkan pengalaman dan pengetahuan yang didapatkan dari seminar dan sharing- sharing dengan relawan lain untuk memberi semangat dan support pada anak-anak jalanan. Subjek kedua "YH" mengatakan bahwa pertolongan relawan sangat penting, baik dari segi fisik misalnya ketika anakanak sedang sakit makan relawan akan menjeguk dan mengantarkan mereka ke rumah sakit, dan dari segi psikis subjek memberikan perhatian dan kasih sayang kepada anak-anak jalanan sehingga mereka bisa mengadu dan bercerita kepada subjek mengenai masalah yang dihadapi dengan harapan anak-anak bisa beraktifitas seperti biasa tanpa ada kendala dan beban karena sebagaimana faktor yang mendorong anak turun ke jalanan menurut Surjana (dalam Siregar dkk., 2006) salah satunya adalah Sebab-sebab yang berasal dari keluarga seperti penelantaran, ketidakmampuan orangtua menyediakan kebutuhan dasar, salah perawatan dari orang tua sehingga mengalami kekerasan di rumah. Adapun cara subjek memotivasi anak jalanan yaitu memotivasi memberikan pembelajaran serta mengobrol dengan anak-anak sehingga mereka merasa termotivasii atas pembelajaran dan nasihat dari para relawan.

\section{Kesimpulan}

Berdasarkan temuan hasil penelitian dapat disimpulkan bahwa gambaran perilaku prososial kedua subjek yaitu membantu tanpa meminta balasan (pamrih), ikhlas, dan jujur dengan harapan dapat membantu banyak pihak seperti pemerintah untuk mengurangi jumlah anak jalanan, membantu masyarakat untuk mengurangi rasa gelisah karena kehadiran anak jalanan dianggap menganggu, dan membantu anak jalanan itu sendiri. Kedua relawan ini memberikan pengajaran atau edukasi kepada anak-anak berdasarkan pengetahuan dan pengalaman yang mereka 
miliki. Selain memberikan pengajaran, kedua relawan juga memberi kontribusi berupa tenaga, uang, fikiran dan pakaian serta alat tulis yang masih layak digunakan. Selanjutnya, faktor-faktor yang mempengaruhi kedua subjek melakukan perilaku prososial yaitu adanya jiwa sosial dan rasa empati yang tinggi terhadap anakanak jalanan sehingga mereka ingin bermanfaat bagi anak jalanan dan masyarakat dengan membantu serta berkontribusi dalam komunitas relawan anak sumatera selatan (RASS).

Adapun saran yang ditujukan oleh peneliti dari hasil penelitian ini adalah sebagai berikut:

\section{Bagi subjek}

Bagi subjek agar lebih memperhatikan dan lebih intens lagi dalam hal membantu anakanak yang benar-benar hidup nya lontanglantung di jalanan terutama yang tidak mempunyai orang tua sebab mereka juga membutuhkan kasih sayang sebagaimana anak pada umumnya tanpa harus berprasangska buruk kepada anak-anak jalanan yang tidak tau asal-usulnya sekalipun melalui perilaku prososial.

\section{Bagi orang tua}

Bagi kedua orang tua hendaknya lebih memperhatikan dan mengawasi anak nya dalam hal pergaulan, karena pada hakikatnya anak-anak membutuhkan kasih sayang dan kesabaran dalam mendidik dan mengajarkannya hingga anak tersebut benar-benar tumbuh mandiri dan bermanfaat bagi orang banyak.

\section{Bagi peneliti selanjutnya}

Bagi peneliti selanjutnya agar melakukan penelitian yang lebih menarik, jauh lebih baik, dan jauh lebih unik tentang gambaran seorang relawan yang melakukan perilaku prososial, dengan metode-metode yang jauh menarik untuk diteliti sehingga penelitian tentang relawan terus semakin berkembang hingga kita menyadari bahwasan nya kehadiran relawan itu amat sangat lah penting.

\section{Referensi}

Adi, R. S. (2005). Ilmu Kesejahteraan Sosial dan Pekerjaan Sosial (Pengantar Pada Pengertian dan Pokok Pembahasan). Jakarta: Fisip UI Press.

Arifin, P. (2001). Pola Pencarian Pengobatan dan Pemeliharaan Kesehatan Anak Jalanan di Kotamadya Yogyakarta. Tesis. Fakultas Kedokteran Universitas Gajah Mada. Yogyakarta.

Asih, G.Y \& Pratiwi, M. (2010). Perilaku Prososial Ditinjau Dari Empati Dan Kematangan Emosi. Jurnal Psikologi Universitas Muria Kudus 1(1).39-40.

Azwar, S. (1998). Metode Penelitian. Yogyakarta: Pustaka Pelajar.

Baron, R. A., \&Byrne, D. (2005). Psikologi sosial. Jilid 2. Alih Bahasa: Ratna Djuwita. Edisi kesepuluh. Jakarta: Erlangga.

Departemen Sosial RI. (2005). Petunjuk Teknis Pelayanan Sosial Anak Jalana. Jakarta: Departemen Sosial Republik Indonesia.

Departemen Sosial RI. (2007). Standart Pelayanan Minimal Pelayanan dan Rehabilitasi Sosial Gelandangan Dan Pengemis. Jakarta: Departemen Sosial Republik Indonesia.

Golmen, D. (2007). Kecerdasan Emosional Jakarta: PT Gramedia Pustaka Utama.

Herdiansyah, H. (2010). Metode Penelitian Kualitatif. Jakarta: Selemba Humanika. 
Hurlock, E.B. (2010). Psikologi Perkembangan Jilid 2. (terjemahan Med. Meitasari Tjandrasa). Jakarta: Gelora Aksara Pratama Erlangga.

Kementrian Sosial RI. (2011). Buku Pedoman Program Desaku Menanti Rehabilitas Sosial Gelandangan Dan Pengemis Terpadu Berbasis Desa. Jakarta: Kementrian Sosial Republik Indonesia.

Lukman, M. L \& Sujarwo. (2012). Kehidupan Anak Jalanan di Rumah Singgah Anak Mandiri Yogyakarta. Jurnal Diklus. 16(2). 162-172.

Miles, M B \& Amichael H. (2007). Analisis Data Kualitatif Buku Sumber tentang Metode-Metode Baru. Terjemahan Tjetjep Rohendi Rohisi. Jakarta: Universitas Indonesia.

Mintanawati, N. (2018). Peran Ikatan Pekerja Sosial Masyarakat (Ipsm) Kota Yogyakartadalam Pemenuhan Hak Anak Jalanan. Jurnal Welfare. 1(2).46-79.

Moleong, L.J. (2013). Metodologi Penelitian Kualitatif. Bandung: Remaja Rosdakarya.

Mutrofin. (2009). Mengapa Mereka Tak Bersekolah. Jakarta: Laks Bang Pressindo.

Perwitasari, D. (2007). Hubungan antara religiusitas dengan perilaku prososial pada mahasiswa psikologi UIN Malang. Skripsi. Universitas Islam Negeri Malang.

Santrock, J. W. (2012). Life-Span Development Jilid 1. Yogyakarta: Penerbit Erlangga.

Sarwono, S.W., \& Meinarno, E.A. (2009). Psikologi Sosial. Jakarta: Penerbit Salemba Humanika.

Siregar. H, Zulkifli.R, \& Suriandi A. (2006). Faktor Dominan Anak Menjadi Anak Jalanan di Kota Medan. Jurnal FISIPUSU: Medan. 1(2).86-96.

Sutopo HB. (2006). Metodologi Penelitian Kualitatif. Surakarta: UNS Press.

Taylor, S. (2009). Psikologi Sosial edisi Kedua belas. Alih Bahasa: Tri
Wibowo. Jakarta: Kencana Prenada Media Group.

Tobing, U.R.I., Nugrgohi, F., Tehuteru, E.S. (2008). Peran Relawan dalam Memberikan Pendampingan Pada Penderita Kanker dan Keluarganya. Indonesia Journal Of Cancer. 3539. 